\title{
Treating Osteoporosis with Oestrogen or Testosterone
}

Amos Gelbard ${ }^{*}$

Zefat Academics Kibbutz Eilon, Galil Maaravi, Israel

*Corresponding author: Amos Gelbard, Zefat Academics Kibbutz Eilon, Galil Maaravi, Israel, Tel: 1-800-344-544; E-mail: amosgelbard@gmail.com Rec date: Nov 02, 2016; Acc date: Nov 14, 2016; Pub date: Nov 16, 2016

Copyright: $\odot 2016$ Gelbard A. This is an open-access article distributed under the terms of the Creative Commons Attribution License, which permits unrestricted use, distribution, and reproduction in any medium, provided the original author and source are credited.

Citation: Gelbard A (2016) Treating Osteoporosis with Oestrogen or Testosterone. J Gerontol Geriatr Res 5: 362. doi:10.4172/2167-7182.1000362

\section{Commentary}

Osteoporosis is a condition in which bone density levels decrease, which leads to fractures and broken bones, usually at an older age. It's most common in postmenopausal women. Low Oestrogen levels have been hypothesized since the 1940 's, by Fuller Albright and his team, to be the reason for Osteoporosis in women [1-3].

Testosterone has also been documented to play a part in bone mineral density in men, also by a Swedish study that showed Testosterone levels in the normal range to be an accurate predictor of healthy BMD in older men [4].

A research from 1969 showed decisive positive results in treating 12 patients, 11 osteoporotic females with oestrogen and 1 osteoporotic male with testosterone [5].

A research from 1983 examined the necessary dosage of oestrogen in treatment of postmenopausal bone loss and showed patients to experience bone loss in doses up to 15 micrograms and bone gain in doses above 25 micrograms of oestrogen [6].
It's therefore plausible to assume the likely effectiveness of testosterone treatment to Osteoporotic men and of oestrogen treatment to osteoporotic women post menopause.

\section{References}

1. Reifenstein EC Jr, Albright F (2002) The metabolic effects of steroid hormones in osteoporosis. J Clin Invest 26: 24-56.

2. Marcus R (2002) Post-menopausal osteoporosis. Stanford University, California, USA.

3. Forbes AP (1991) Fuller Albright. His concept of postmenopausal osteoporosis and what came of it. Clin Orthop Relat Res 269: 128-141.

4. Mellström D, Johnell O, Ljunggren O, Eriksson AL, Lorentzon M, et al. (2006) Free testosterone is an independent predictor of BMD and prevalent fractures in elderly men: MrOS Sweden. J Bone Miner Res 21: 529-535.

5. Riggs BL, Jowsey J, Kelly PJ, Jones JD, Maher FT (1969) Effect of sex hormones on bone in primary osteoporosis. J Clin Invest 48: 1065-1072.

6. Horsman A, Jones M, Francis R, Nordin C (1983) The effect of estrogen dose on postmenopausal bone loss. N Engl J Med 309: 1405-1407. 